ORIGINAL ARTICLE

\title{
The favourable prognostic value of oestrogen receptor $\beta$ immunohistochemical expression in breast cancer
}

\author{
L Nakopoulou, A C Lazaris, E G Panayotopoulou, I Giannopoulou, N Givalos, S Markaki, \\ A Keramopoulos
}

J Clin Pathol 2004;57:523-528. doi: 10.1136/jcp.2003.008599

See end of article for authors' affiliations

......................

Correspondence to: Dr L Nakopoulou, Department of Pathology Medical School, National and Kapodistrian University of Athens, 75 Mikras Assias Street, Goudi, GR-115 27 Athens, Greece; Inakopou@cc.voa.gr/ alazaris@med.voa.gr

Accepted for publication 11 April 2003

\begin{abstract}
Aims: Oestrogen receptor $\beta(E R \beta)$ is present in breast tumours, although its prognostic and pathophysiological roles remain to be established.

Methods: Standard immunohistochemistry with a specific monoclonal antibody was performed on paraffin wax embedded sections; $10 \%$ of strongly immunostained carcinoma cells was used as the cutoff point to classify tumours as ER $\beta$ positive. Statistical correlations were sought with clinicopathological variables (including hormone receptor status) and disease free (DFS) and overall survival (OS) in a well documented series of 181 invasive breast carcinomas. Cell proliferation was assessed immunohistochemically by topoisomerase lla (Topolla) index; p53 protein accumulation and c-erbB-2 oncoprotein expression were also taken into account.

Results: ER $\beta$ immunoreactivity was detected in most specimens (71.2\%); it was positively linked to ER $\alpha$ immunoreactivity and increased Topoll $\alpha$ index, and inversely to c-erbB-2 overexpression. There were no correlations with p53 immunostaining or other clinicopathological parameters. A significant favourable impact of ER $\beta$ immunopositivity emerged with regard to DFS and OS in both univariate and multivariate analysis; ER $\beta$ immunopositivity retained its favourable significance with regard to DFS in the subgroups of stage I and II patients when they were examined separately. Progesterone receptor expression also had an independent favourable influence on survival, albeit with less significance. In contrast, survival was not significantly influenced by $\mathrm{ER} \alpha$ status.

Conclusions: Because of the positive association between ER $\beta$ immunoreactivity and Topoll $\alpha$ expression, the presence of ER $\beta$ in breast cancer cells could be considered an indication of increased proliferation. Nevertheless, ER $\beta$ immunoreactivity emerges as a valuable, independent indicator of favourable prognosis.
\end{abstract}

The function of ER $\beta$ in breast pathobiology remains unclear, ${ }^{38}$ partly because most studies have focused on its mRNA rather than the protein. ${ }^{12}$ Large studies with multivariate analysis are needed to confirm the independent predictive value of ER $\beta .^{71}$

\section{"Oestrogen receptor $\alpha$ and $\beta$ have distinct cellular distributions, regulate separate sets of genes, and can oppose each other's actions on some genes"}

Our present study was undertaken to investigate the relation between ER $\beta$ immunohistochemical expression and various clinicopathological variables, including disease free and overall patient survival in a large series of invasive breast carcinomas.

\section{METHODS}

\section{Patient sample}

Our study comprised 181 women with $\mathrm{M}_{0}$ invasive breast cancer, either ductal invasive of no special type $(n=149)$ or lobular invasive $(n=32)$. They had undergone segmental resection or mastectomy and had received no preoperative chemotherapy or endocrine treatment. Information was recorded concerning the patient's age at surgery (mean, 61

$\| \alpha$ 
Table 1 Clinicopathological characteristics of the patients

\begin{tabular}{|c|c|c|c|}
\hline \multirow[b]{2}{*}{ Variables } & \multicolumn{3}{|c|}{ Number of patients (\%) expressing ERß } \\
\hline & $<10 \%$ & $10-40 \%$ & $>40 \%$ \\
\hline \multicolumn{4}{|l|}{ Menopausal status } \\
\hline Before menopause $(n=39)$ & $12(30.7 \%)$ & $17(43.5 \%)$ & $10(25.6 \%)$ \\
\hline After menopause $(n=142)$ & $40(28.1 \%)$ & $54(38 \%)$ & $48(33.8 \%)$ \\
\hline \multicolumn{4}{|l|}{ Tumour maximum diameter } \\
\hline$<2 \mathrm{~cm}(\mathrm{n}=49)$ & $12(24.4 \%)$ & $20(40.8 \%)$ & $17(34.7 \%)$ \\
\hline$>2 \mathrm{~cm}(\mathrm{n}=132)$ & $40(30.3 \%)$ & $51(38.6 \%)$ & $41(31 \%)$ \\
\hline \multicolumn{4}{|l|}{ Histological type } \\
\hline $\begin{array}{l}\text { Invasive ductal not otherwise specified } \\
(n=149)\end{array}$ & 41 (27.5\%) & $63(42.3 \%)$ & $45(30.2 \%)$ \\
\hline Invasive lobular $(n=32)$ & $11(34.3 \%)$ & $8(25 \%)$ & $13(40.6 \%)$ \\
\hline \multicolumn{4}{|l|}{$\begin{array}{l}\text { Histological grade (in ductal invasive } \\
\text { carcinomas only) }\end{array}$} \\
\hline I $(n=13)$ & $4(30.7 \%)$ & $7(53.8 \%)$ & $2(15.4 \%)$ \\
\hline$\|(n=91)$ & $24(26.4 \%)$ & $37(40.6 \%)$ & $30(33 \%)$ \\
\hline III $(n=43)$ & $12(27.9 \%)$ & $19(44.2 \%)$ & $12(27.9 \%)$ \\
\hline \multicolumn{4}{|l|}{ Nuclear grade } \\
\hline $1(n=71)$ & $17(24 \%)$ & $29(40.8 \%)$ & $25(35.2 \%)$ \\
\hline$\|(n=60)$ & $17(28.3 \%)$ & $20(33.3 \%)$ & $23(38.3 \%)$ \\
\hline III $(n=47)$ & $16(34 \%)$ & $21(44.7 \%)$ & $10(21.3 \%)$ \\
\hline \multicolumn{4}{|l|}{ Lymph node status } \\
\hline Tumour free $(n=69)$ & $16(23.2 \%)$ & $27(39.1 \%)$ & $26(37.7 \%)$ \\
\hline Tumour infiltrated $(n=112)$ & $36(32.1 \%)$ & $44(39.3 \%)$ & $32(28.6 \%)$ \\
\hline \multicolumn{4}{|l|}{ Stage } \\
\hline I $(n=29)$ & $6(20.7 \%)$ & $12(41.4 \%)$ & $11(38 \%)$ \\
\hline$\|(n=126)$ & $37(29.4 \%)$ & $46(36.5 \%)$ & $43(34.1 \%)$ \\
\hline III $(n=26)$ & $9(34.6 \%)$ & $13(50 \%)$ & $4(15.4 \%)$ \\
\hline \multicolumn{4}{|l|}{$E R \alpha$ immunostatus } \\
\hline Negative $(n=61)$ & $27(44.3 \%)$ & $24(39.3 \%)$ & $10(16.4 \%)$ \\
\hline Positive $(n=117)$ & $23(19.6 \%)$ & $46(39.3 \%)$ & $48(41 \%)$ \\
\hline \multicolumn{4}{|l|}{ PR immunostatus } \\
\hline Negative $(n=91)$ & $28(30.8 \%)$ & $35(38.5 \%)$ & $28(30.8 \%)$ \\
\hline Positive $(n=87)$ & $22(25.3 \%)$ & $35(40.2 \%)$ & $30(34.5 \%)$ \\
\hline
\end{tabular}

years; SEM, 1; range, 36-88), menopausal status, tumour size, the pathological diagnosis according to standard criteria, ${ }^{13-15}$ stage of disease (according to UICC criteria), ${ }^{14}$ and $\mathrm{ER} \alpha$ and progesterone receptor (PR) positivity, as determined immunohistochemically ${ }^{16}$ (table 1). Additional data concerning the expression of several immunohistochemical markers (c-erbB-2 oncoprotein overexpression (cutoff point, 10\%; antibody clone, CB 11; Biogenex, San Ramon, California, USA), p53 protein accumulation, antiapoptotic protein Bcl-2, topoisomerase II $\alpha$ (TopoII $\alpha$ ), and tissue inhibitor of metalloproteinases 1 (TIMP-1) expression in cancer cells (cutoff point, 30\%; antibody clone, 147-6D11; Medicorp, Montreal, Canada)) were available from previous studies. ${ }^{16-18}$ After initial breast cancer surgery, the patients received adjuvant tamoxifen treatment for one to five years, irrespective of $\mathrm{ER} \alpha$ status or other clinicopathological factors; stage II and III patients mainly received adjuvant chemoendocrine treatment using cyclophosphamide, methotrexate, 5-fluorouracil, and tamoxifen for two years. Because our present study investigates the prognostic value of ER $\beta$ alone, and not its ability to predict the response to tamoxifen, a non-tamoxifen control arm was not necessary.

\section{Immunohistochemistry}

For ER $\beta$ immunostaining, paraffin wax embedded sections $(4 \mu \mathrm{m})$ were dewaxed in xylene and rehydrated through graduated ethanol to water. The samples were stained in four runs after strict standardisation of the staining procedure. Endogenous peroxidase was blocked by incubation for 30 minutes with a solution of $1 \%$ hydrogen peroxide, and antigen retrieval was performed by autoclaving sections in $0.01 \mathrm{M}$ citrate buffer, $\mathrm{pH} 6.0$, for 20 minutes at $800 \mathrm{~W}$. The Serotec ER $\beta$ mouse monoclonal antibody (clone PPG5/10; Raleigh, North Carolina, USA) was applied at a dilution of 1 / 25. As an immunogen, a synthetic peptide derived from the
C-terminus of the human ER $\beta 1$ isoform was used; this type of antibody is specific for ER $\beta$ protein and does not crossreact with ER $\alpha$ protein. ${ }^{19}$ Biotinylated secondary antibody and avidin-biotin kits were obtained from Vector Laboratories (Burlingame, California, USA). For substitute negative controls, the primary antibody was replaced with phosphate buffered saline alone. Immunostaining of the normal ductal epithelial cells adjacent to cancer tissues was used as a positive internal control for ER $\beta$. Sections of tonsillar lymphoid tissue served as negative controls.

\section{Assessment of tissue staining}

The slides were examined by two observers who were blinded to the clinicopathological features of the patients. The percentage of positively stained cells was an average after counting the intensely stained and the total number of cancer cells from at least 10 high power fields; when the evaluations differed, final agreement was reached by consensus using a two headed microscope. In parallel with Mann et al, ${ }^{11}$ ER $\beta$ positivity was defined as nuclear staining in more than $10 \%$ of the cancer cells; this cutoff point was associated with better survival in both Mann's study and ours. After having taken into account the mean percentage of ER $\beta$ positive cells in the immunopositive cases, we divided them as follows: cases with "low" positivity (percentages of immunoreactive cells between $10 \%$ and $40 \%$ ) and cases with high positivity (percentages $>40 \%$ ). When assessing ER $\alpha$ and both relapse free and overall survival, $10 \%$ was used as the cutoff point to discriminate between $E R \alpha$ negative and $E R \alpha$ positive cases.

\section{Statistical analysis}

Chi square tests were used to compare the distribution of ER $\beta$ expression with all categorical variables of interest. The association of TopoII $\alpha$ with ER $\beta$ expression was examined by one way analysis of variance after logarithmic transformation 
of the data. Univariate analyses were performed using the log rank test to establish the value of each variable as a separate predictor of overall survival/disease free survival. The results are illustrated by Kaplan-Meier curves. Cox's proportional hazard model was used to identify those variables that were independent predictors of overall survival and disease free survival. Significance was set at 5\%.

\section{RESULTS}

\section{ERß immunostaining}

One hundred and twenty nine of $181(71.2 \%)$ tumours were defined as ER $\beta$ positive; in these receptor positive specimens, the abundance of cells containing ER $\beta$ varied from $12 \%$ to $82 \%$ (median, $35 \%)$. In the $\mathrm{ER} \alpha^{+} / \mathrm{ER} \beta^{+}$phenotype $(\mathrm{n}=94)$, $\mathrm{ER} \alpha$ was always expressed in greater amounts than ER $\beta$. In general, strong ER $\beta$ nuclear immunoreactivity was seen both in cancer cells and tumour adjacent, morphologically normal, ductal epithelium (figs 1 and 2). The in situ component of the tumour, when noticeable, was characteristised by immunostaining similar to that of the invasive compartment. ER $\beta$ (but not ER $\alpha$ ) was also focally present in the nuclei of cells other than epithelial cells, in both "normal" and tumoral structures, particularly in fibroblasts.

\section{ERß relations to clinicopathological variables}

ER $\beta$ immunostaining did not differ with regard to patients' menopausal status $\left(\chi^{2}=0.949 ; \mathrm{p}=0.622\right)$, tumour size $\left(\chi^{2}=2.136 ; p=0.711\right)$, lymph node status $\left(\chi^{2}=2.298 ;\right.$ $\mathrm{p}=0.317)$, stage $\left(\chi^{2}=4.761 ; \mathrm{p}=0.313\right)$, histological type $\left(\chi^{2}=3.530 ; \mathrm{p}=0.171\right)$, histological grade of differentiation $\left(\chi^{2}=1.836 ; \mathrm{p}=0.766\right)$, nuclear grade of malignancy $\left(\chi^{2}=4.564 ; \mathrm{p}=0.335\right)$, PR status $\left(\chi^{2}=0.699\right.$; $\mathrm{p}=0.705), \mathrm{p} 53$ protein accumulation $\left(\chi^{2}=3.779\right.$; $\mathrm{p}=0.151), \quad$ bcl-2 immunoreactivity $\quad\left(\chi^{2}=1.157\right.$; $\mathrm{p}=0.561)$, or TIMP-1 protein expression in stromal cells $\left(\chi^{2}=2.245 ; \mathrm{p}=0.326\right)$. ER $\beta$ immunostaining was positively related to $\mathrm{ER} \alpha$ immunostaining $\left(\chi^{2}=16.107\right.$; $\mathrm{p}=0.001$; fig $3 \mathrm{~A})$, in addition to TopoII $\alpha$ quantitative expression (TopoII $\alpha$ index) $(\mathrm{F}=3.255 ; \mathrm{p}=0.045$; fig $3 \mathrm{~B}$ ) and TIMP-1 protein overexpression in cancer cells $\left(\chi^{2}=13.287 ; \mathrm{p}=0.001\right.$; fig 3C). ER $\beta$ immunopositivity was inversely associated with overexpression of the c-erbB-2 oncoprotein $\left(\chi^{2}=6.513 ; p=0.039\right.$; fig 3D).

\section{ERß and survival}

Patients were followed every three months postoperatively (mean follow up period, 76 months; SD, 26). During the follow up period, 42 patients died of their disease and 57 patients developed recurrence. Systemic recurrence was

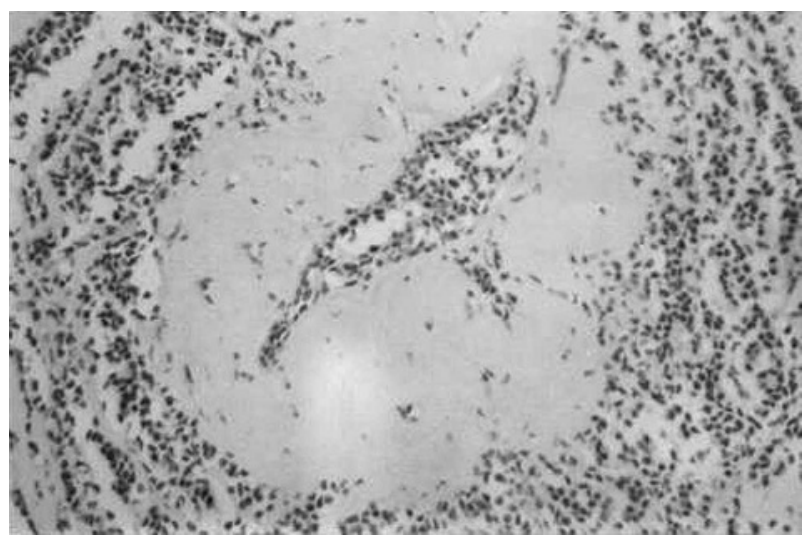

Figure 1 Intense oestrogen receptor $\beta$ immunopositivity in the nuclei of a lobular invasive carcinoma (avidin-biotin complex immunohistochemical stain; original magnification, $\times 250$ ).

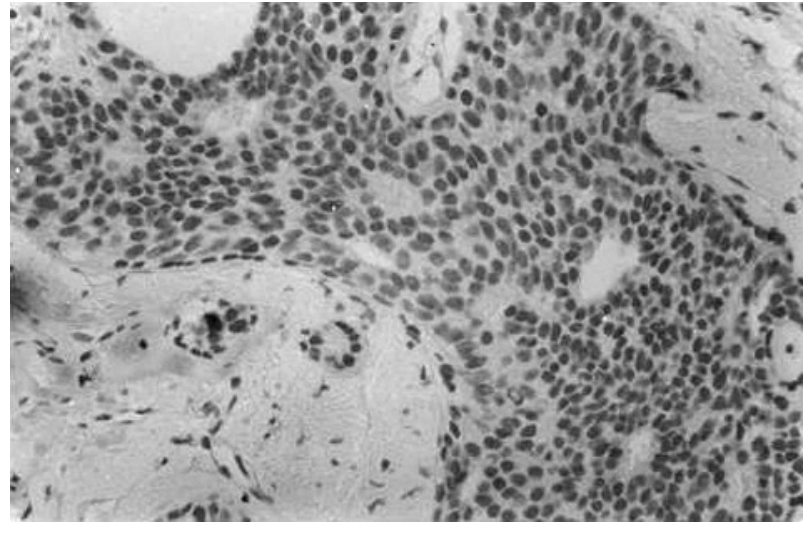

Figure 2 Oestrogen receptor $\beta$ immunodetection in both malignant cells and normal ductules (lower left) (avidin-biotin complex immunohistochemical stain; original magnification, $\times 300$ ).

noticed in 47 patients; in nine of these last patients concomitant locoregional recurrences were observed. Only local recurrence was noticed in 10 patients. As far as relapse free survival is concerned, in univariate statistical analysis, ER $\beta$ immunopositivity appeared to exert a favourable influence both on its own (log rank, $p=0.0002$; fig 4C) and combined with ER $\alpha$ immunopositivity (log rank, $\mathrm{p}=0.0008$; fig $4 \mathrm{D})$. In Cox's regression analysis, ER $\beta$ immunoreactivity emerged as a strong favourable prognosticator, along with PR positivity, although PR positivity had a lesser influence; disease free survival was also significantly influenced by lymph node status, TopoII $\alpha$ index, p53 accumulation, and stage. ER $\alpha$ immunolabelling did not affect relapse time (table 2 ). With regard to overall survival, ER $\beta$ immunopositivity was again an important favourable prognostic indicator, both on its own ( $\log$ rank, $\mathrm{p}=0.0002$; fig $4 \mathrm{~A}$ ) and in combination with ER $\alpha$ immunoreactivity (log rank, $\mathrm{p}=0.0039$; fig 4B). When each stage was separately evaluated, log rank tests showed that ER $\beta$ immunopositivity had a significant influence on relapse free survival of stage I and II patients ( $p=0.0168$ and $p=0.0045$, respectively) and in overall survival of stage II and III patients ( $\mathrm{p}=0.0089$ and $\mathrm{p}=0.0307$, respectively). In multivariate analysis, stage was the most powerful prognostic indicator; ER $\beta$ expression retained its significant favourable influence, being the second most powerful prognostic factor. TopoII $\alpha$ index and PR status also emerged as important independent prognostic indicators, whereas ER $\alpha$ status by itself was again not found to influence overall survival (table 3 ). Interestingly, with regard to the combined ER $\beta / E R \alpha$ immunophenotype, both disease free and overall survival were significantly longer in patients with ER $\beta / E R \alpha$ double immunopositive tumours; the second most favourable immunophenotype was $E R \beta^{+} / E R \alpha^{-}, E R \beta^{-} / E R \alpha^{+}$was next and, finally, patients with tumours simultaneously negative for ER $\beta$ and $\mathrm{ER} \alpha$ had the worst prognosis (fig 4B, D).

\section{DISCUSSION}

In accordance with previous immunohistochemical studies, ${ }^{3}{ }^{2021}$ ER $\beta$ was expressed in a considerable proportion of carcinomas, in addition to non-malignant breast ducts. The observation that both ERs are expressed in morphologically normal ductal epithelium implies that ER $\beta$ probably has a function in the normal mammary gland. Despite previously reported correlations in smaller series ${ }^{71}$ between ER $\beta$ immunoreactivity and premenopausal/perimenopausal status, histological low grade, lack of axillary node metastasis, and PR status, we found no associations between ER $\beta$ immunostaining and these clinicopathological factors. These 

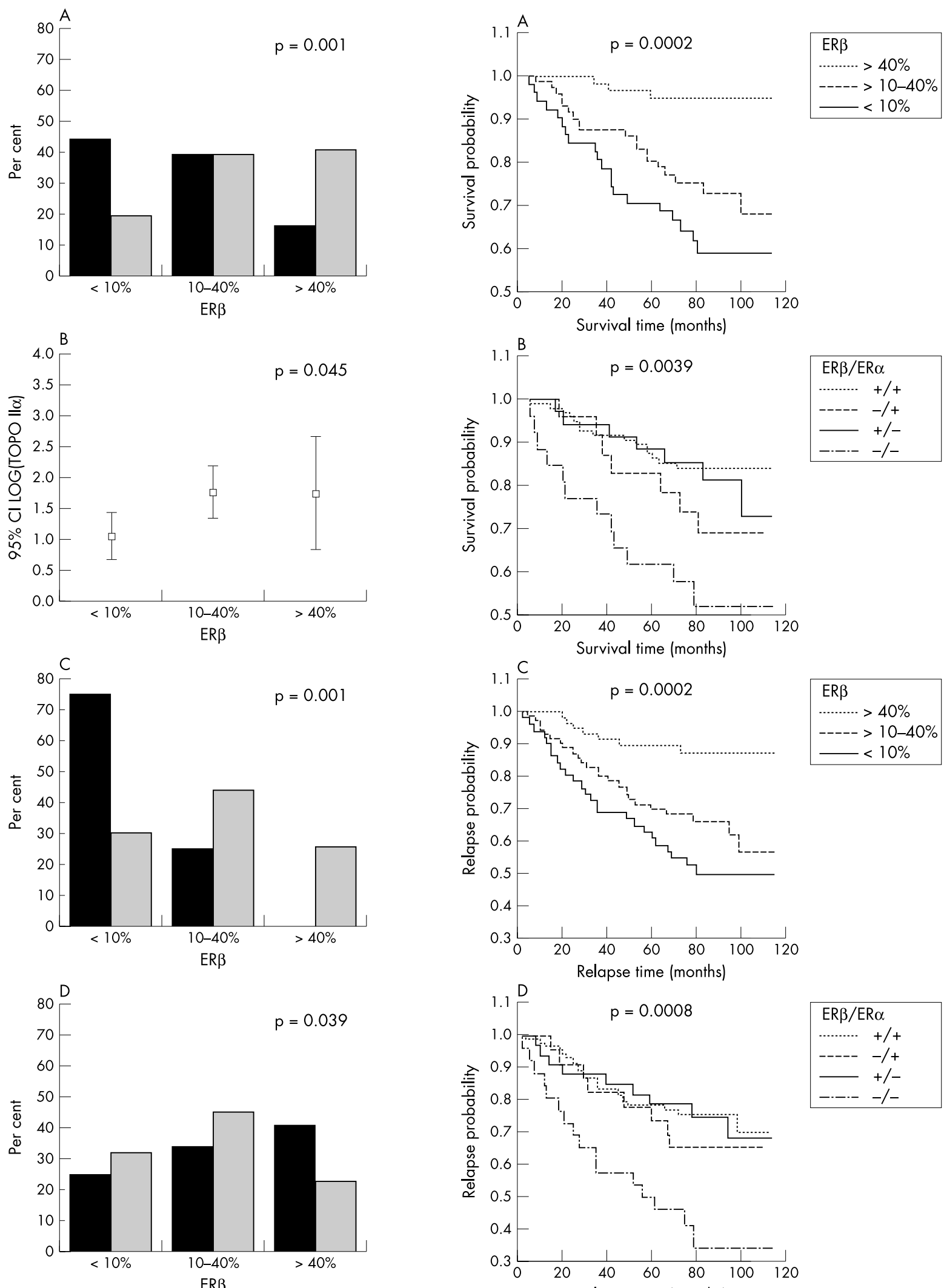

Figure 3 Statistical associations of $(A)$ oestrogen receptor $\beta$ (ER $\beta$ ) immunopositivity and $E R \alpha$ expression in cancer cells (ER $\alpha$ negative, black bars; $E R \alpha$ positive, shaded bars); (B) ER $\beta$ immunopositivity and topoisomerase lla index in cancer cells; (C) ERß immunopositivity and tissue inhibitor of metalloproteinases 1 (TIMP-1) expression in cancer cells $(<30 \%$ cells positive, black bars; $>30 \%$ cells positive, shaded bars); and (D) c-erbB-2 expression in cancer cells (c-erbB-2 negative, black bars; c-erbB-2 positive, shaded bars).

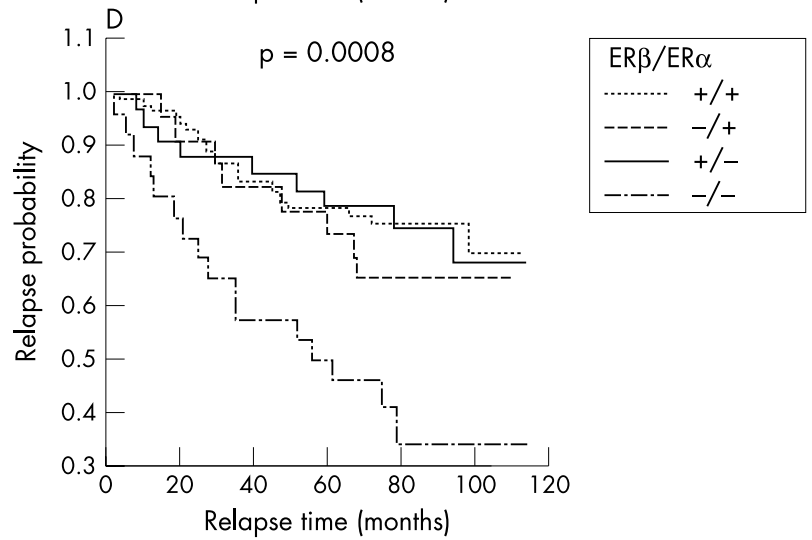

Figure 4 The prognostic impact of oestrogen receptor (ER)

immunopositivity on disease free and overall survival (all patients; log rank tests).

earlier studies ${ }^{721}$ used a polyclonal and a different monoclonal antibody to the one used in our study. In our series, using the PPG5/10 monoclonal antibody, we found a 
Table 2 Cox's regression analysis of the prognostic value of the evaluated parameters with regard to disease free survival

\begin{tabular}{lllllll}
\hline & B & SE & df & p Value & HR & 95\% Cl \\
\hline ER $\beta$ status & -1.333 & 0.403 & 1 & 0.001 & 0.264 & 0.120 to 0.580 \\
Lymph node status & 0.851 & 0.310 & 1 & 0.006 & 2.342 & 1.274 to 4.302 \\
Stage & 1.154 & 0.446 & 1 & 0.010 & 3.172 & 1.324 to 7.597 \\
Topoll $\alpha$ index & 0.039 & 0.018 & 1 & 0.032 & 1.039 & 1.003 to 1.077 \\
p53 accumulation & 0.945 & 0.446 & 1 & 0.034 & 2.573 & 1.074 to 6.166 \\
PR status & -0.817 & 0.407 & 1 & 0.045 & 0.442 & 0.199 to 0.981 \\
Tumour size & & & & 0.722 & & \\
Histological grade & & & & 0.822 & & \\
Nuclear grade & & & & 0.622 & & \\
ER $\alpha$ status & & & & 0.966 & & \\
c-erbB-2 overexpression & & & & & & \\
\hline
\end{tabular}

$\mathrm{Cl}$, confidence interval; $\mathrm{df}$, degrees of freedom; ER, oestrogen receptor; PR, progesterone receptor; Topoll $\alpha$, topoisomerase $\| \alpha$.

significant association between positive ER $\beta$ status and positive ER $\alpha$ status, in addition to lack of c-erbB-2 oncoprotein overexpression, reinforcing the findings of other investigators. $^{720-22}$

In contrast to ER $\alpha$ status, ${ }^{9}$ ER $\beta$ status appears to be independent of PR status; ${ }^{20}{ }^{23}$ in other words, unlike ER $\alpha$, ER $\beta$ does not appear to induce PR. Transcription of the PR gene is enhanced and maintained by oestrogens; thus, a positive PR status has long been regarded as a marker of a functional ER pathway. According to our findings, ER $\beta$ does not seem to be an important factor defining the expression of PR in breast cancer; this may indicate indirectly that ER $\beta$ has a smaller role in defining the responsiveness to hormonal treatment in breast cancer. In those tissues that exclusively express either $\mathrm{ER} \alpha$ or $\mathrm{ER} \beta$, signalling would be via the specific receptor, whereas in those tissues expressing both subtypes, signalling would be mediated by ER $\alpha / \operatorname{ER} \beta$ heterodimers. ${ }^{24}$ It could be hypothesised that one function of ER $\beta$ is to antagonise the effects of ER $\alpha$ in epithelial cells. Because one of the main functions of ER $\alpha$ in the epithelium is the induction of PR, it is possible that an ER $\alpha / E R \beta$ heterodimer can inhibit this action. ${ }^{23}$

The molecular study of Bièche et al found no definite associations between activation and cell proliferation. In our present immunohistochemical study, ER $\beta$ immunopositivity was positively associated with a reliable marker of actively proliferating cells in breast cancer, TopoII $\alpha$. This molecule is a cycle related enzyme that functions in the segregation of newly replicated chromosome pairs in chromosome conden-

Table 3 Cox's regression analysis of the prognostic value of the assessed variables with regard to overall survival

\begin{tabular}{|c|c|c|c|c|c|c|}
\hline & B & SE & $d f$ & p Value & HR & $95 \% \mathrm{Cl}$ \\
\hline Stage & 1.331 & 0.394 & 1 & 0.001 & 3.783 & $\begin{array}{l}1.747 \text { to } \\
8.193\end{array}$ \\
\hline$E R \beta$ status & -0.957 & 0.376 & 1 & 0.011 & 0.384 & $\begin{array}{l}0.184 \text { to } \\
0.802\end{array}$ \\
\hline Topoll $\alpha$ index & 0.038 & 0.018 & 1 & 0.030 & 1.039 & $\begin{array}{l}1.004 \text { to } \\
1.075\end{array}$ \\
\hline PR status & -0.956 & 0.467 & 1 & 0.041 & 0.384 & $\begin{array}{l}0.154 \text { to } \\
0.960\end{array}$ \\
\hline Tumour size & & & & 0.999 & & \\
\hline Lymph node status & & & & 0.096 & & \\
\hline Histological grade & & & & 0.427 & & \\
\hline Nuclear grade & & & & 0.411 & & \\
\hline$E R \alpha$ status & & & & 0.833 & & \\
\hline $\begin{array}{l}\text { c-erbB-2 } \\
\text { overexpression }\end{array}$ & & & & 0.068 & & \\
\hline
\end{tabular}

$\mathrm{Cl}$, confidence interval; $\mathrm{df}$, degrees of freedom; ER, oestrogen receptor; $\mathrm{PR}$, progesterone receptor; Topoll $\alpha$, topoisomerase Il $\alpha$. sations and in altering DNA superhelicity. TopoIIa is thought to provide an exact measure of the growth fraction and its increased expression has been positively associated in breast cancer with more commonly used proliferation markers, such as Ki-67. ${ }^{172526}$ The view that ER $\beta$ is important in cell proliferation in breast cancer has been discussed in a previous study, where the expression of ER $\beta$ was associated with a higher content of Ki-67 and cyclin A; in that study, in specimens where ER $\beta$ was much more abundant than ER $\alpha$, there were many Ki-67 positive cells, $98 \%$ of which expressed ER $\beta .^{3}$ In contrast, ER $\alpha$ expressing cells in breast cancer do not express proliferation markers, ${ }^{8}$ so that it is possible that ER $\beta$ and not ER $\alpha$ is related to proliferation in breast cancer. The proliferative action of oestrogen on the epithelium is indirect-oestrogen is thought to stimulate the secretion of growth factors from breast stroma and these factors stimulate epithelial cells to proliferate. ${ }^{8}$ Interestingly, ER $\beta$ mRNA positive cancers are more frequently epidermal growth factor receptor protein positive than their negative counterparts. ${ }^{27}$ Two distinct types of responses to oestrogen in the breast have been described, ${ }^{4}$ namely: (a) an indirect action of oestradiol in the mammary epithelium by inducing ER containing stromal cells to produce growth factors that stimulate epithelial cells to divide, and (b) a direct effect on ER $\alpha$ containing cells that occurs at low oestrogen concentrations and results in the induction of PR. As far as the breast carcinomas in our present study are concerned, the detection of ER $\beta$ in tumour stromal elements and the lack of correlation between ER $\beta$ and PR status lead us to suggest that ER $\beta$ is involved in the first type of oestrogen response. In any case, our finding that ER $\beta$ positive carcinomas have a proliferative advantage potentially illuminates the role of ER $\beta$ selective antagonists as a useful addition to the therapeutic regimen with a novel target-namely proliferating cells expressing ER $\beta$ - which, probably, are not targets of tamoxifen; it is accepted that the beneficial effect of tamoxifen in breast cancer is caused by its effect on ER $\alpha$ positive cells, very few of which are proliferating. ${ }^{3}$

\section{"In our present series, multivariate statistical analysis revealed no significant influence of oestrogen receptor $\alpha$ status on survival, whereas patients with oestrogen receptor $\beta$ positive tumours had an improved longterm prognosis"}

With regard to its prognostic value, ER $\beta$ immunoreactivity was positively correlated with one potentially favourable prognosticator-TIMP-1 protein overexpression-in cancer cells. TIMP-1 protein expression is a potential marker of decreased malignant potential in breast cancer and can act as a multifunctional protein involved in matrix architecture 


\section{Take home messages}

- Oestrogen receptor $\beta$ (ER $\beta$ ) immunopositivity had a significantly favourable impact on disease free survival and overall survival in patients with breast cancer in both univariate and multivariate analysis

- This was despite the fact that there was a positive association between ER $\beta$ immunoreactivity and topoisomerase $\| l \alpha$ expression, indicating that ER $\beta$ is associated with increased proliferation

preservation and cell differentiation. ${ }^{28}$ ER $\beta$ immunopositivity was inversely associated with a predictor of poor prognosisoverexpression of the c-erbB-2 oncoprotein.

Despite these correlations, ER $\beta$ immunopositivity emerged as an independent indicator of favourable prognosis with regard to both disease free and overall survival. It is of particular interest that ER $\beta$ immunostatus appears to have clinical significance with regard to the relapse free survival of stage I patients. In contrast to the proposed prognostic impact of ER $\beta, E R \alpha$ is now considered a weak prognostic factor. According to recent reports, ER $\alpha$ positive tumours may have a more indolent course during the first years after primary breast cancer treatment; however, longterm disease free and overall survival are not significantly affected by ER $\alpha$ status in the primary tumour in terms of the natural aggressiveness of the tumour. ${ }^{29}$ In our present series, multivariate statistical analysis revealed no significant influence of ER $\alpha$ status on survival, whereas patients with ER $\beta$ positive tumours had an improved longterm prognosis. To the best of our knowledge, this is the first time that the independent value of ER $\beta$ immunoreactivity on prognosis in breast cancer has been reported. Nevertheless, the finding that ER $\beta$ immunopositivity emerged as an independent indicator of favourable prognosis, despite the fact that ER $\beta$ positivity was associated with a proliferative advantage, requires verification in other series, which should examine whether this favourable prognostic influence results purely or partly from the fact that all patients received tamoxifen.

In conclusion, we found that although the ER $\beta$ protein is associated with increased cell proliferation it could be useful as an indicator of good prognosis in breast cancer.

\section{ACKNOWLEDGMENTS}

This study was financially supported by the Bank of Greece. The authors acknowledge the excellent technical assistance of $\mathrm{J}$ Mavrommatis, doctoral fellow.

\section{Authors' affiliations \\ L Nakopoulou, A C Lazaris, E G Panayotopoulou, I Giannopoulou, N Givalos, Department of Pathology, Medical School, National and Kapodistrian University of Athens, 75 Mikras Assias Street, Goudi, GR-115 27 Athens, Greece}

S Markaki, Department of Pathology, "Alexandra" Hospital, GR-115 28 Athens, Greece

A Keramopoulos, First Department of Gynaecology and Obstetrics, School of Medicine, National and Kapodistrian University of Athens

\section{REFERENCES}

1 Fitzgibbons PL, Page DL, Weaver D, et al. Prognostic factors in breast cancer. College of American Pathologists' Consensus Statement 1999. Arch Pathol Lab Med 2000;124:966-78.

2 Harvey JM, Clark GM, Osborne CK, et al. Estrogen receptor status by immunohistochemistry is superior to the ligand-binding assay for predicting response to adjuvant endocrine therapy in breast cancer. $J$ Clin Oncol 1999;17:1474-81.

3 Jensen EV, Chen G, Palmieri C, et al. Estrogen receptors and proliferation markers in primary and recurrent breast cancer. Proc Natl Acad Sci U S A 2001;98:15197-202.

4 Saji S, Jensen EV, Nilsson S, et al. Estrogen receptors $\alpha$ and $\beta$ in the rodent mammary gland. Proc Natl Acad Sci U S A 2000;97:337-42.

5 Speirs V, Skliris GP, Burdall SE, et al. Distinct expression patterns of ER $\alpha$ and ER $\beta$ in normal human mammary gland. J Clin Pathol 2002;55:371-4.

6 Saunders PTK, Millar MR, Williams K, et al. Expression of oestrogen receptor beta (ER $\beta$ ) protein in human breast cancer biopsies. Br J Cancer 2002;86:250-6.

7 Järvinen TAH, Pelto-Huikko $M$, Holli K, et al. Estrogen receptor $\beta$ is coexpressed with $E R \alpha$ and $P R$ and associated with nodal status, grade and proliferation rate in breast cancer. Am J Pathol 2000;156:29-35.

8 Palmieri C, Cheng GJ, Saji S, et al. Estrogen receptor beta in breast cancer. Endocr Relat Cancer 2002;9:1-13.

9 Bièche I, Parfait B, Laurendeau I, et al. Quantification of estrogen receptor $\alpha$ and $\beta$ expression in sporadic breast cancer. Oncogene 2001;20:8109-115.

10 Lazennec $G$, Bresson D, Lucas $A$, et al. ER $\beta$ inhibits proliferation and invasion of breast cancer cells. Endocrinology 2001;142:4120-30.

11 Mann S, Laucirica R, Carlson N, et al. Estrogen receptor beta expression in invasive breast cancer. Hum Pathol 2001;32:113-18.

12 Speirs V. Oestrogen receptor beta in breast cancer: good, bad or still too early to tell? J Pathol 2002;197:143-7.

13 WHO. Histological typing of breast tumours. In: Hartman WH, Uzello L, Sobin $\mathrm{LH}$, et al. International histological classification of tumours. Geneva: World Health Organisation, 1981:15-25

14 Rosen PP, Oberman HA. Tumors of the mammary gland. In: Rosai J, ed. Atlas of tumor pathology. Washington: Armed Forces Institute of Pathology, 1992:3-7.

15 Robbins P, Pinder S, De Klerk N. Histological grading of breast carcinomas: a study of interobserver agreement. Hum Pathol 1995;28:873-9.

16 Nakopoulou L, Michalopoulou A, Giannopoulou I, et al. Bcl-2 protein expression is associated with a prognostically favourable phenotype in breast cancer irrespective of p53 immunostaining. Histopathology 1999;34:310-19.

17 Nakopoulou L, Lazaris AC, Kavantzas N, et al. DNA topoisomerase II-alpha immunoreactivity as a marker of tumor aggressiveness in invasive breast cancer. Pathobiology 2000;68:137-43.

18 Nakopoulou L, Zervas A, Lazaris ACh, et al. Predictive value of topoisomerase lla immunostaining in urothelial bladder carcinoma. J Clin Pathol 2001;54:309-13.

19 Girdler F, Browell DA, Cunliffe WJ, et al. Use of the monoclonal antibody DAKO-ERbeta (8D5-1) to measure oestrogen receptor beta in breast cance cells. Cytometry 2001;45:65-72.

20 Omoto $Y$, Inove S, Ogawa S, et al. Clinical value of the wild-type estrogen receptor $\beta$ expression in breast cancer. Cancer Lett 2001;163:207-12.

21 Skliris GP, Carder PJ, Lansdown MRJ, et al. Immunohistochemical detection of $E R \beta$ in breast cancer: towards more detailed receptor profiling? $\mathrm{Br} J$ Cancer 2001;84:1095-8.

22 Kurebayashi J, Otsuki T, Kunisue H, et al. Expression levels of estrogen receptor-alpha, estrogen receptor-beta, coactivators, and corepressors in breast cancer. Clin Cancer Res 2000;6:512-18.

23 Miyoshi Y, Taguchi T, Gustafsson J- $\AA$, et al. Clinicopathological characteristics of estrogen receptor- $\beta$-positive human breast cancers. Jpn J Cancer Res 2001;92:1057-61.

24 Speirs V, Parkes AT, Kerin MJ, et al. Coexpression of estrogen receptor $\alpha$ and $\beta$ : poor prognostic factors in human breast cancer? Cancer Res 1999:59:525-8.

25 Rudolph P, Olsson H, Bonatz G, et al. Correlation between p53, c-erbB-2, and topoisomerase II alpha expression, DNA ploidy, hormonal receptor status and proliferation in 356 node-negative breast carcinomas: prognostic implications. J Pathol 1999;187:207-16.

26 Lynch BJ, Guinee DG Jr, Holden JA. Human DNA topoisomerase II-alpha: a new marker of cell proliferation in invasive breast cancer. Hum Pathol 1997;28:1180-8.

27 Knowlden JM, Gee JM, Robertson JF, et al. A possible divergent role for the oestrogen receptor alpha and beta subtypes in clinical breast cancer. Int J Cancer 2000;89:209-12.

28 Nakopoulou L, Giannopoulou I, Lazaris AC, et al. The favorable prognostic impact of tissue inhibitor of matrix metalloproteinases-1 protein expression in breast cancer cells. APMIS 2003;111:1027-36.

29 Kent Osborne C. Steroid hormone receptors in breast cancer management. Breast Cancer Res Treat 1998;51:227-38. 